\title{
Homeobox protein CDX2 as a prognostic biomarker in solid malignancies: a meta-analysis
}

\author{
Jingsheng Yuan ${ }^{1}$, Zhijie Yin ${ }^{1}$, Kaixiong Tao ${ }^{1}$, Guobing Wang ${ }^{1}$ and Jinbo Gao ${ }^{1}$ \\ ${ }^{1}$ Department of Gastrointestinal Surgery, Union Hospital, Tongji Medical College, Huazhong University of Science and \\ Technology, Wuhan, China
}

Correspondence to: Jinbo Gao, email: jgao@hust.edu.cn

Keywords: CDX2, prognosis, solid malignancies, meta-analysis, biomarker

Received: July 11, 2017 Accepted: August 17, $2017 \quad$ Published: September 11, 2017

Copyright: Yuan et al. This is an open-access article distributed under the terms of the Creative Commons Attribution License 3.0 (CC BY 3.0), which permits unrestricted use, distribution, and reproduction in any medium, provided the original author and source are credited.

\section{ABSTRACT}

Background: CDX2 is a caudal-homeobox gene and its expression is abnormal in numerous tumour cell types. Nevertheless, its prognostic value for solid tumours requires further investigation. Hence, we conducted a meta-analysis to determine the significance of CDX2 as a prognostic biomarker in solid malignancies systematically.

Materials and Methods: We performed a systematic literature search in PUBMED and EMBASE up to May 2017. Retrospective studies comparing the prognostic value of different CDX2 levels in human malignancies were included. Data extractions and methodological assessments were performed separately by two investigators using a standard procedure. The statistical procedures were performed using Review Manager 5.3 and STATA/MP 14.0.

Results: A total of $\mathbf{2 6}$ retrospective studies met the inclusion criteria and comprised 5008 participants. Patients with CDX2 overexpression had significantly better 3-year, 5-year, 10-year and disease-free survival outcomes in solid malignancies, regardless of the cancer type, mean age, and source region. Nevertheless, there was no significant difference in the patients from Europe. The expression level of CDX2 was not statistically associated with cancer relapse. Moreover, our analysis showed that CDX2 overexpression is correlated to better responses to chemotherapy in patients with TNM IV stage cancers. The stability of the pooled outcomes was verified by sensitivity analysis. The funnel plots, Egger's test and Begg's test jointly confirmed that there was no publication bias.

Conclusions: Overexpression of CDX2 is a reliable biomarker of a better prognosis in solid malignancies.

\section{INTRODUCTION}

Over the past decade, steady improvements in the overall survival (OS) and disease-free survival (DFS) outcomes have been observed in cancer patients, depending on the availability of new adjuvant treatment regimens. However, no reliable biomarker exists that enables stratification of patients with high-risk diseases for appropriate therapy. Patients with early stage tumours are often cured with surgery alone, but many patients will relapse and eventually succumb to their diseases [1]. Identifying which molecules can predict the cancer prognosis and adjuvant therapeutic benefit remains a research priority.
$C D X 2$ is a caudal-homeobox gene which is mostly expressed in intestinal epithelial cells. CDX2 expression is essential to the intestinal epithelial proliferation and the differentiation and maintenance of the intestinal phenotypes $[2,3]$. Considerable studies have confirmed that $\mathrm{CDX} 2$ is expressed not only in normal intestinal epithelial cells but also in different cancer cell types and functions as a tumour suppressor $[4,5]$. Moreover, various clinical studies suggest that CDX2 expression is often lost in cancers with high tumour grade and advanced tumour stage $[6,7]$.

A previous study evaluated the expression levels of CDX2 and its association with the clinicopathological characteristics of gastric cancers [6], but the independent 
prognostic value of CDX2 remains controversial. Braak et al reported that there is no association between CDX2 expression and the prognosis of colon cancer patients [8], whereas Li et al suggested that CDX2 expression would be useful for predicting the prognosis of gallbladder carcinomas [9]. In our study, we aimed to perform a more comprehensive quantitative assessment with a meta-analysis and to determine the value of CDX2 as a prognostic and predictive tumour biomarker.

\section{RESULTS}

\section{Study and patient characteristics}

Among 1313 studies that were identified in our literature search, 26 retrospective studies (consisting of 28 cohorts) met the inclusion criteria (a flow diagram is provided in Figure 1). The total sample size comprised 5008 participants, individually ranging from 40 to 713 per study with a median value of 108 patients. Most of the 26 studies were carried out in Asia $(n=14)$ and Europe $(n=7)$, and the remaining five were performed in the USA; these studies mainly focused on colorectal cancers $(n=9)$ and gastric cancers $(n=8)$. Other detailed features are included in Table 1 [10-35].

\section{Methodological assessment}

The Newcastle-Ottawa Quality Assessment Scale (NOS) quality score ranged from 5 to 9 , and the assessment included two 5-score studies, eight 6-score studies, ten 7-score studies, five 8-score studies and one 9-score study. The 5-score studies included Jamieson 2013 and Wong 2011, the low score was mainly due to their unrepresentative study cohorts (Supplementary Table 1).

\section{Correlations between CDX2 levels and 3-year overall survival}

23 retrospective studies offered original data on 3 -year OS in terms of different CDX2 expressions. Compared with lower CDX2 expression, patients with CDX2 positivity had significantly better 3-year OS outcomes, along with a moderate heterogeneity of undefined source (OR: 0.29, 95\%CI: [0.22,0.37], $P<0.00001, I^{2}=49 \%$ ) (Figure 2).

Subgroup analysis by cancer types showed that CDX2 overexpression was a prognostic biomarker of a favourable 3-year OS for participants with gastric cancer (OR: 0.34, 95\%CI: [0.20,0.58], $P<0.0001, I^{2}=$ 67\%), colorectal cancer (OR: $0.32,95 \% \mathrm{CI}$ : [0.20,0.49], $P<0.00001, I^{2}=55 \%$ ) and other cancer types (OR: 0.22, 95\%CI: [0.16,0.31], $P<0.00001, I^{2}=0 \%$ ) (Figure 3).

According to the subgroup analysis of different mean age ranges, regardless of whether the mean age was $<60$ (OR: 0.26, 95\%CI: [0.16,0.41], $P<0.00001$,
$I^{2}=18 \%$ ), between 60 and $<65$ (OR: 0.26 , 95\%CI: [0.20,0.34], $\left.P<0.00001, I^{2}=8 \%\right),>65$ (OR: $0.18,95 \% \mathrm{CI}$ : [0.08,0.39], $P<0.0001, I^{2}=0 \%$ ) or unknown (OR: 0.41, 95\%CI: [0.23,0.73], $P=0.002, I^{2}=73 \%$ ), high CDX2 expression was invariably associated with a better 3-year OS for patients with solid malignancies (Supplementary Figure 1).

All included studies were then divided into three subgroups according to the source regions of the cancer patients. For patients from Asia (OR: 0.26, 95\%CI: $\left.[0.21,0.33], P<0.00001, I^{2}=0 \%\right)$ and other regions (OR: 0.22 , 95\%CI: [0.12,0.41], $P<0.00001, I^{2}=52 \%$ ), excessive CDX2 expression was linked to increased 3 -year OS. Nevertheless, there was no significant difference in patients from Europe (OR: 0.50, 95\%CI: [0.22,1.13], $P=$ $0.10, I^{2}=78 \%$ ).

In the subgroup analysis by sample sizes, elevated CDX2 expression was confirmed to play a favourable prognostic role in terms of 3-year OS in solid malignancies, no matter whether the number of participants was smaller $(<100)(\mathrm{OR}: 0.38$, 95\%CI: [0.22,0.67], $\left.P=0.0008, I^{2}=60 \%\right)$ or larger $(>100)(\mathrm{OR}:$ $0.26,95 \% \mathrm{CI}:[0.21,0.32], P<0.00001, I^{2}=23 \%$ ).

\section{Correlations between CDX2 levels and 5-year overall survival}

The original data of 5-year OS in terms of different CDX2 expressions was extracted from 24 retrospective studies. Our pooled results indicated that CDX2 overexpression played a favourable role on the 5-year OS rate in solid malignancies (OR: $0.31,95 \% \mathrm{CI}$ : [0.23,0.41], $P<0.00001)$ (Figure 4). A high heterogeneity was observed $\left(I^{2}=62 \%\right)$. We stratified the original data for subgroup analysis to further explore the potential sources of heterogeneity across studies.

With respect to subgroups by different cancer types, a high CDX2 level reflected a favourable 5-year OS for patients with gastric cancer (OR: 0.32, 95\%CI: [0.18,0.55], $P<0.0001, I^{2}=71 \%$ ), colorectal cancer (OR: $0.37,95 \% \mathrm{CI}$ : $\left.[0.25,0.56], P<0.00001, I^{2}=52 \%\right)$ and other cancer types (OR: 0.20 , 95\%CI: [0.11,0.36], $P<0.00001, I^{2}=53 \%$ ) (Figure 5).

High CDX2 level in different mean-age subgroups also suggested a better 5-year OS for cancer patients with a mean age that either was $<60$ (OR: $0.32,95 \% \mathrm{CI}$ : $\left.[0.18,0.56], P<0.0001, I^{2}=41 \%\right)$, between 60 and $<65$ (OR: 0.26, 95\%CI: [0.18,0.37], $P<0.00001, I^{2}=42 \%$ ), $>65$ (OR: $0.09,95 \% \mathrm{CI}$ : [0.03,0.26], $P<0.0001, I^{2}=10 \%$ ) or unknown (OR: 0.47, 95\%CI: [0.28,0.78], $P=0.003$, $\left.I^{2}=69 \%\right)$ (Supplementary Figure 1).

As for the source regions of solid malignancies, excessive CDX2 positivity was significantly correlated with a better 5-year OS in patients from Asia (OR: 0.27, 95\%CI: $[0.21,0.34], P<0.00001, I^{2}=12 \%$ ) and other regions (OR: $0.21,95 \% \mathrm{CI}$ : [0.08,0.53], $P=0.001, I^{2}=73 \%$ ). However, 
Table 1: Demographic information for included studies with CDX2 expression

\begin{tabular}{|c|c|c|c|c|c|c|c|c|c|}
\hline Reference & Country & Cancer type & No. & Mean age(y) & $\begin{array}{l}\text { Male/Female } \\
\text { (The percentage of } \\
\text { females) }\end{array}$ & $\begin{array}{l}\text { TNM } \\
\text { stage }\end{array}$ & $\begin{array}{l}\text { Median } \\
\text { follow- } \\
\text { up(m) }\end{array}$ & $\begin{array}{l}\text { CDX2 } \\
(-/+)\end{array}$ & $\begin{array}{l}\text { NOS } \\
\text { score }\end{array}$ \\
\hline $\begin{array}{l}\text { Baba et al. } \\
2009\end{array}$ & USA & $\begin{array}{l}\text { Colorectal } \\
\text { cancer }\end{array}$ & 598 & NA & NA & I-IV & NA & $172 / 426$ & 9 \\
\hline $\begin{array}{l}\text { Bae et al. } \\
2015\end{array}$ & Korea & $\begin{array}{l}\text { Colorectal } \\
\text { cancer }\end{array}$ & 713 & 62 & $434 / 279(39.13)$ & I-IV & 56.5 & $42 / 671$ & 8 \\
\hline $\begin{array}{l}\text { Bai et al. } \\
2013\end{array}$ & China & Gastric cancer & 228 & $60.72 \pm 12.95$ & $170 / 58(25.44)$ & I-IV & NA & $129 / 99$ & 7 \\
\hline $\begin{array}{l}\text { Camilo et } \\
\text { al. } 2014\end{array}$ & Portugal & Gastric cancer & 94 & 64.6 & $124 / 77(38.31)$ & I-IV & NA & $55 / 39$ & 6 \\
\hline $\begin{array}{l}\text { Dalerba et } \\
\text { al. } 2016\end{array}$ & USA & $\begin{array}{l}\text { Colon } \\
\text { cancer-C1 }\end{array}$ & 314 & NA & NA & II/III & NA & $38 / 276$ & 8 \\
\hline $\begin{array}{l}\text { Dalerba et } \\
\text { al. } 2016\end{array}$ & USA & $\begin{array}{l}\text { Colon } \\
\text { cancer-C2 }\end{array}$ & 466 & NA & NA & II/III & NA & $32 / 434$ & 8 \\
\hline $\begin{array}{l}\text { Fan et al. } \\
2005\end{array}$ & China & Gastric cancer & 109 & 59 & $75 / 34(31.19)$ & I-IV & NA & $69 / 40$ & 7 \\
\hline $\begin{array}{l}\text { Hansel et } \\
\text { al. } 2005\end{array}$ & USA & $\begin{array}{l}\text { Periampullary } \\
\text { cancer }\end{array}$ & 53 & 68 & $30 / 23(44.40)$ & I-IV & NA & $39 / 14$ & 6 \\
\hline $\begin{array}{l}\text { Hong et al. } \\
2013\end{array}$ & Korea & $\begin{array}{l}\text { Colorectal } \\
\text { cancer }\end{array}$ & 207 & $62.3 \pm 11.4$ & $119 / 88(42.51)$ & I-IV & 65.8 & $11 / 196$ & 7 \\
\hline $\begin{array}{l}\text { Huang et al. } \\
2012\end{array}$ & China & Ovarian cancer & 182 & NA & NA & I-IV & 36.2 & $129 / 53$ & 7 \\
\hline $\begin{array}{l}\text { Jamieson et } \\
\text { al. } 2013\end{array}$ & USA & $\begin{array}{l}\text { Pancreatic } \\
\text { ductal cancer }\end{array}$ & 60 & NA & NA & NA & NA & $47 / 13$ & 5 \\
\hline $\begin{array}{l}\text { Jun et al. } \\
2014\end{array}$ & Korea & $\begin{array}{l}\text { Small intestinal } \\
\text { cancer }\end{array}$ & 189 & $59 \pm 14$ & $118 / 71(37.57)$ & I-IV & 28.1 & $107 / 82$ & 7 \\
\hline $\begin{array}{l}\text { Kim et al. } \\
2013\end{array}$ & Korea & $\begin{array}{l}\text { Colorectal } \\
\text { cancer }\end{array}$ & 109 & NA & $66 / 43(39.45)$ & I-IV & NA & $15 / 94$ & 6 \\
\hline $\begin{array}{l}\text { Kumari } \\
\text { et al. } 2013\end{array}$ & India & $\begin{array}{l}\text { Periampullary } \\
\text { cancer }\end{array}$ & 108 & 57.2 & $74 / 34(31.48)$ & I-III & NA & $65 / 43$ & 6 \\
\hline $\begin{array}{l}\text { Lundberg } \\
\text { et al. } 2016\end{array}$ & Sweden & $\begin{array}{l}\text { Colorectal } \\
\text { cancer }\end{array}$ & 431 & NA & $231 / 200(46.40)$ & I-IV & NA & $62 / 369$ & 8 \\
\hline $\begin{array}{l}\text { Matsuda } \\
\text { et al. } 2010\end{array}$ & Japan & $\begin{array}{l}\text { Colorectal } \\
\text { cancer }\end{array}$ & 97 & 68 & NA & I-IV & NA & $9 / 88$ & 6 \\
\hline $\begin{array}{l}\text { Mizoshita } \\
\text { et al. } 2003\end{array}$ & Japan & Gastric cancer & 177 & $63.2 \pm 11.1$ & $105 / 72(40.68)$ & I-IV & NA & $88 / 89$ & 7 \\
\hline $\begin{array}{l}\text { Perysinakis } \\
\text { et al. } 2016\end{array}$ & Greece & $\begin{array}{l}\text { Ampullary } \\
\text { cancer }\end{array}$ & 47 & $66.3 \pm 12.5$ & $27 / 20(42.55)$ & I-IV & 52 & $19 / 28$ & 6 \\
\hline $\begin{array}{l}\text { Pilati et al. } \\
2017\end{array}$ & France & $\begin{array}{l}\text { Colon } \\
\text { cancer-C1 }\end{array}$ & 79 & NA & NA & II/III & NA & $39 / 40$ & 8 \\
\hline $\begin{array}{l}\text { Pilati et al. } \\
2017\end{array}$ & France & $\begin{array}{l}\text { Colon } \\
\text { cancer-C2 }\end{array}$ & 99 & NA & NA & II/III & NA & $23 / 76$ & 8 \\
\hline $\begin{array}{l}\text { Qin et al. } \\
2012\end{array}$ & China & Gastric cancer & 85 & 61.75 & $60 / 25(29.41)$ & I-IV & NA & $44 / 41$ & 7 \\
\hline $\begin{array}{l}\text { Schildberg } \\
\text { et al. } 2014\end{array}$ & Germany & Gastric cancer & 79 & NA & NA & NA & 88 & $52 / 27$ & 7 \\
\hline $\begin{array}{l}\text { Seno et al. } \\
2002\end{array}$ & Japan & Gastric cancer & 40 & 61 & $26 / 14(35.00)$ & I-IV & NA & $22 / 18$ & 6 \\
\hline $\begin{array}{l}\text { Treese et al. } \\
2016\end{array}$ & Germany & $\begin{array}{l}\text { Gastro- } \\
\text { Oesophageal } \\
\text { cancer }\end{array}$ & 65 & 62.9 & $81 / 48(37.21)$ & I-IV & NA & $28 / 37$ & 6 \\
\hline
\end{tabular}




\begin{tabular}{|l|l|l|l|l|l|l|l|l|l|}
\hline $\begin{array}{l}\text { Wong et al. } \\
2011\end{array}$ & China & $\begin{array}{l}\text { Colorectal } \\
\text { cancer }\end{array}$ & 64 & NA & NA & I-IV & NA & $32 / 32$ & 5 \\
\hline $\begin{array}{l}\text { Xiao et al. } \\
2014\end{array}$ & USA & $\begin{array}{l}\text { Pancreatic } \\
\text { ductal cancer }\end{array}$ & 61 & 64 & $32 / 29(47.54)$ & NA & NA & $39 / 22$ & 7 \\
\hline $\begin{array}{l}\text { Zhang et al. } \\
2009\end{array}$ & Japan & Gastric cancer & 109 & $62.43 \pm 10.12$ & $63 / 46(42.20)$ & I-IV & NA & $52 / 57$ & 8 \\
\hline $\begin{array}{l}\text { Zhang et al. } \\
2016\end{array}$ & USA & $\begin{array}{l}\text { Metastatic } \\
\text { colorectal } \\
\text { cancer }\end{array}$ & 145 & 63.6 & $69 / 76(52.41)$ & IV & NA & $66 / 79$ & 7 \\
\hline
\end{tabular}

No.: number; y: year; m: month; NOS: Newcastle-Ottawa

Scale; NA: not available; C1: cohort 1; C2: cohort 2.

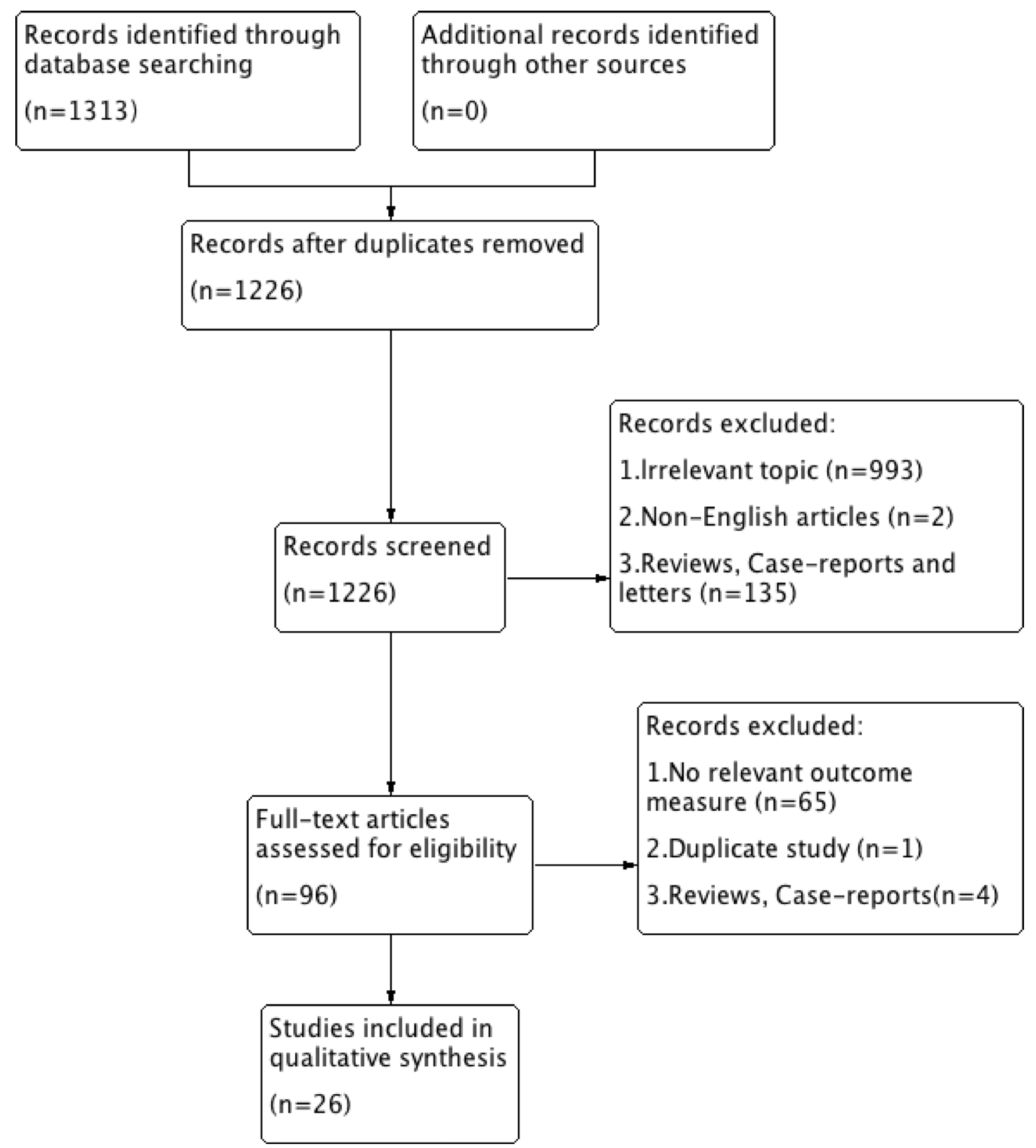

Figure 1: Selection flow diagram of this meta-analysis. 
no correlation between CDX2 expression and 5-year OS was evident for European patients (OR: 0.54, 95\%CI: [0.26,1.12], $P=0.1, I^{2}=74 \%$ ) (Supplementary Figure 4).

For the subgroup determined by sample size of the studies, the pooled analysis showed that CDX2 positivity had a strong connection with a better 5-year OS in solid malignancies, regardless of whether the sample size was smaller (<100) (OR: 0.30, 95\%CI: [0.15,0.60], $P=0.0007$, $\left.I^{2}=73 \%\right)$ or larger $(>100)(\mathrm{OR}: 0.30,95 \% \mathrm{CI}$ : [0.23,0.38], $P<0.00001, I^{2}=40 \%$ ) (Supplementary Figure 2).

\section{Correlations between CDX2 levels and 10-year overall survival}

Concerning the 10-year OS in solid malignancies, only 7 studies offered original data in terms of different CDX2 expressions. In our pooling analysis, a high CDX2 positivity in solid malignancies corresponded to a significantly better 10 -year OS rate (OR: $0.36,95 \% \mathrm{CI}$ : $[0.20,0.65], P=0.0007$ ) (Figure 6). A high heterogeneity was observed across studies $\left(I^{2}=77 \%\right)$.

\section{Correlations between CDX2 levels and Disease- free survival}

The merged outcome showed that a better prognosis was observed concerning 3-year (OR: 0.50, 95\%CI: [0.25,0.98], $P=0.04, I^{2}=65 \%$ ) and 5-year DFS (OR:
$0.45,95 \% \mathrm{CI}:[0.25,0.81], P=0.008, I^{2}=56 \%$ ) among the malignancies with CDX2 overexpression, along with a high heterogeneity (Supplementary Figure 5).

\section{Correlations between CDX2 levels and cancer relapse}

A comparable number of patients with relapsed disease was observed regardless of whether the CDX2 levels (OR: 0.93, 95\%CI: [0.39,2.25], $P=0.87, I^{2}=70 \%$ ) (Figure 7).

Stratified by cancer types of the included studies, the CDX2 expression levels in colorectal cancer (OR: $0.80,95 \% \mathrm{CI}$ : $[0.20,3.25], P=0.75, I^{2}=79 \%$ ) and ovarian cancer (OR: $1.23,95 \% \mathrm{CI}$ : [0.65,2.34], $P=0.52$ ) were irrelevant to disease relapse (Figure 8).

According to the subgroup analysis of different TNM stages, the numbers of relapsed patients with TNM II/III (OR: 1.36, 95\%CI: [0.28,6.68], $P=0.70, I^{2}=80 \%$ ) and TNM I-IV (OR: 0.60, 95\%CI: [0.12,3.08], $P=0.54$, $I^{2}=78 \%$ ) stage diseases were statistically equivalent regardless of the CDX2 expression levels (Figure 8).

\section{Correlations between CDX2 levels and chemotherapeutic effects}

The original data on the correlations between CDX2 levels and the effects of adjuvant chemotherapy

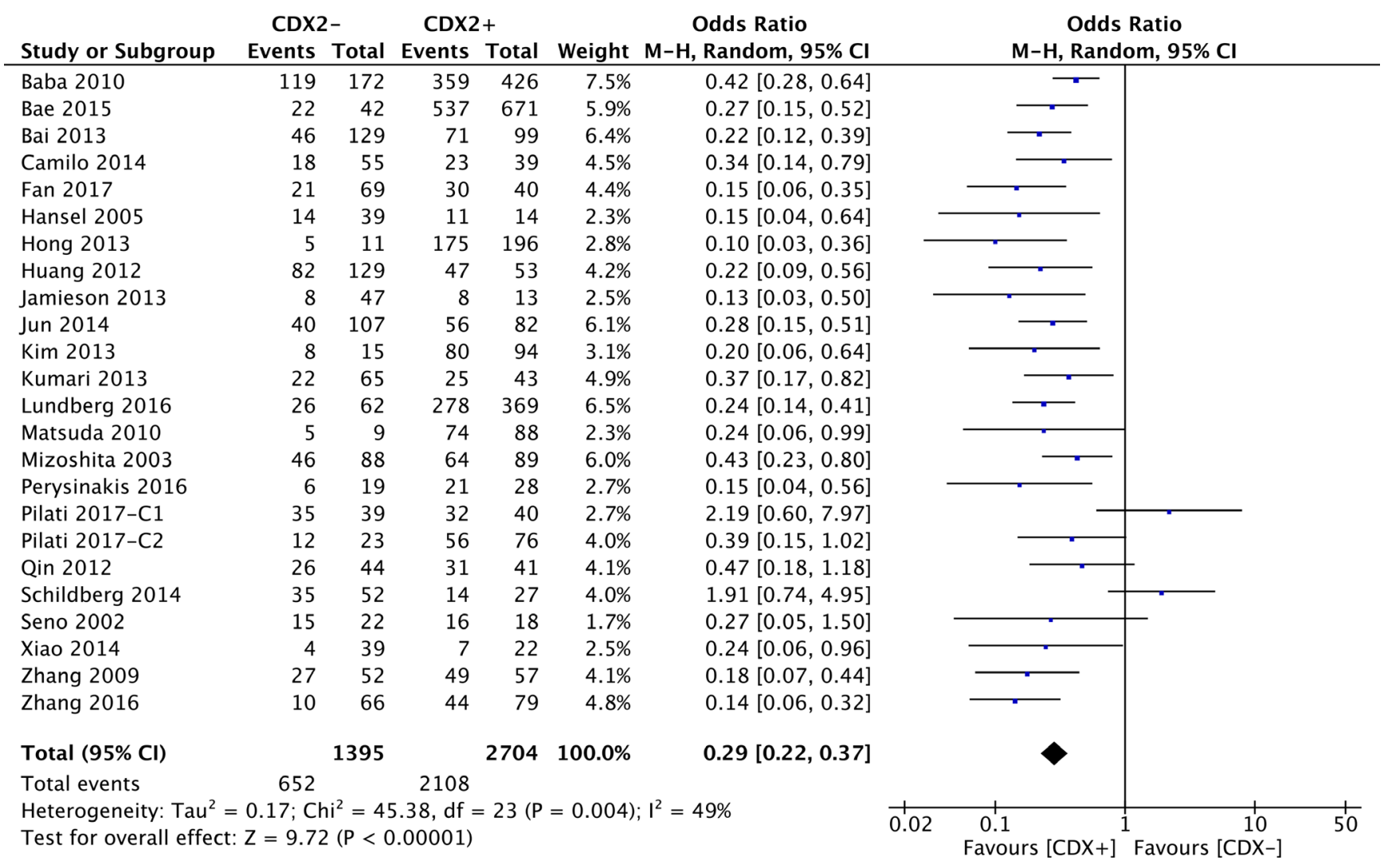

Figure 2: Forest plot of the association between CDX2 expression and 3-year overall survival in solid malignancies. 
CDX2-

$\mathrm{CDX} 2+$

Odds Ratio

Study or Subgroup Events Total Events Total Weight M-H, Random, 95\% C

$0.22[0.12,0.39]$ 6.3.1 Gastric cancer of 3-year OS

Bai 2013

Camilo 2014

Fan 2017

Mizoshita 2003

Qin 2012

Schildberg 2014

Seno 2002

Zhang 2009

Subtotal $(95 \% \mathrm{CI})$

Total events

$\begin{array}{rr}46 & 129 \\ 18 & 55\end{array}$

$\begin{array}{llll}29 & 71 & 99 & 6.4 \%\end{array}$

$0.34[0.14,0.79]$

$0.15[0.06,0.35]$

$0.43[0.23,0.80]$

$0.47[0.18,1.18]$

$1.91[0.74,4.95]$

$0.27[0.05,1.50]$

$0.18[0.07,0.44$

234

298

$0.34[0.20,0.58$

Heterogeneity: $\mathrm{Tau}^{2}=0.37 \cdot \mathrm{Chi}^{2}=21.44, \mathrm{df}=7(\mathbf{P}=0.003) ; \mathrm{I}^{2}=67 \%$

Test for overall effect: $Z=3.98(P<0.0001)$

6.3.2 Colorectal cancer of 3-year OS

$\begin{array}{lllllll}\text { Baba } 2010 & 119 & 172 & 359 & 426 & 7.5 \%\end{array}$

Bae 2015

Hong 2013

Kim 2013

Lundberg 2016

Matsuda 2010

Pilati 2017-C

Pilati $2017-\mathrm{C} 2$
Subtotal $(95 \% \mathrm{Cl})$

Total events

$\begin{array}{lllll}22 & 42 & 537 & 671 & 5.9 \%\end{array}$

$\begin{array}{lll}175 & 196 & 2.8 \%\end{array}$

$\begin{array}{rrrrr}8 & 15 & 80 & 94 & 3.1 \%\end{array}$

Heterogeneity: $\mathrm{Tau}^{2}=0.20 ; \mathrm{Chi}^{2}=15.73, \mathrm{df}=7(\mathrm{P}=0.03) ; \mathrm{I}^{2}=55 \%$

Test for overall effect: $Z=5.09(P<0.00001)$

6.3.3 Other types of 3-year OS

$\begin{array}{llllll}\text { Hansel } 2005 & 14 & 39 & 11 & 14 & 2.3 \%\end{array}$

$\begin{array}{llllll}\text { Huang } 2012 & 82 & 129 & 47 & 53 & 4.2 \%\end{array}$

Jamieson 2013

Jun 2014

Kumari 2013

Perysinakis 2016

Xiao 2014

Zhang 2016

Subtotal $(95 \% \mathrm{CI})$

$\begin{array}{rr}82 & 129 \\ 8 & 47\end{array}$

$\begin{array}{rrrrr}8 & 47 & 8 & 13 & 2.5 \%\end{array}$

$\begin{array}{lllll}40 & 107 & 56 & 82 & 6.1 \%\end{array}$

$\begin{array}{rrrrr}22 & 65 & 25 & 43 & 4.9 \% \\ 6 & 19 & 21 & 28 & 2.7 \%\end{array}$

$10 \quad 66$

Total events $\quad 186$

219

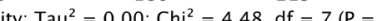

Test for overall effect: $Z=8.89(P<0.00001)$

$\begin{array}{lllll}\text { Total }(95 \% \mathrm{Cl}) & 1395 & 2704 & 100.0 \% & 0.29[0.22,0.37]\end{array}$

Total events $652 \quad 2108$

Heterogeneity: $\mathrm{Tau}^{2}=0.17 ; \mathrm{Chi}^{2}=45.38, \mathrm{df}=23(\mathrm{P}=0.004) ; \mathrm{I}^{2}=49 \%$

Test for overall effect: $Z=9.72(P<0.00001)$

Test for subgroup differences: $\mathrm{Chi}^{2}=2.54, \mathrm{df}=2(\mathrm{P}=0.28), \mathrm{I}^{2}=21.2 \%$

$0.42[0.28,0.64]$ $0.27[0.15,0.52]$

$0.10[0.03,0.36]$

$0.20[0.06,0.64]$

$0.24[0.14,0.41]$

$0.24[0.06,0.99$

$2.19[0.60,7.97]$

$0.32[0.20,0.49]$

$0.15[0.04,0.64]$ $0.22[0.09,0.56]$ $0.13[0.03,0.50]$ $0.28[0.15,0.51]$ $0.37[0.17,0.82]$ $0.15[0.04,0.56]$ $0.24[0.06,0.96]$ $0.14[0.06,0.32$

Random, 95\%

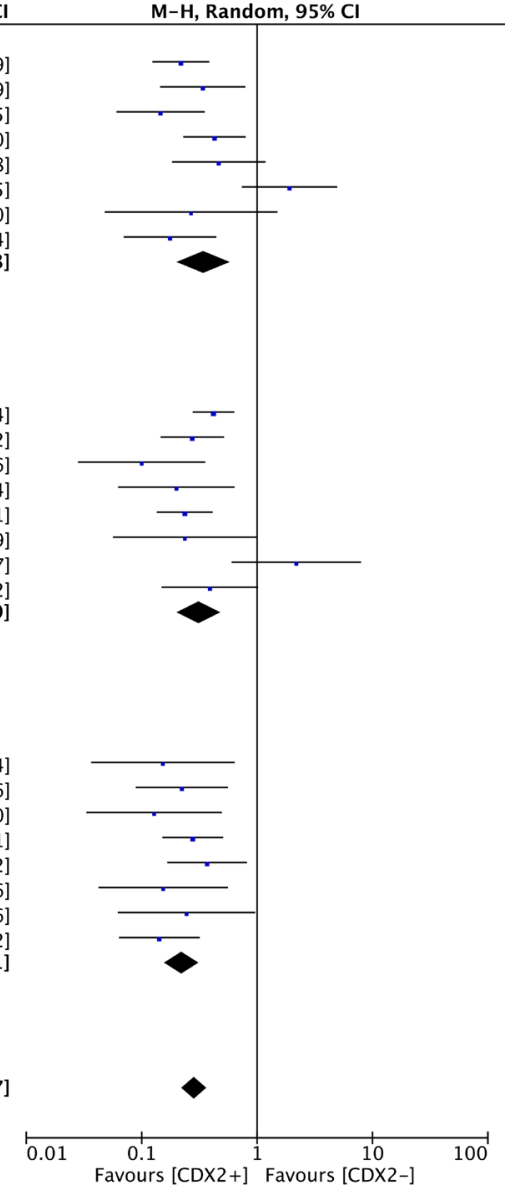

Figure 3: The correlation between CDX2 expression and 3-year overall survival based on different cancer types.

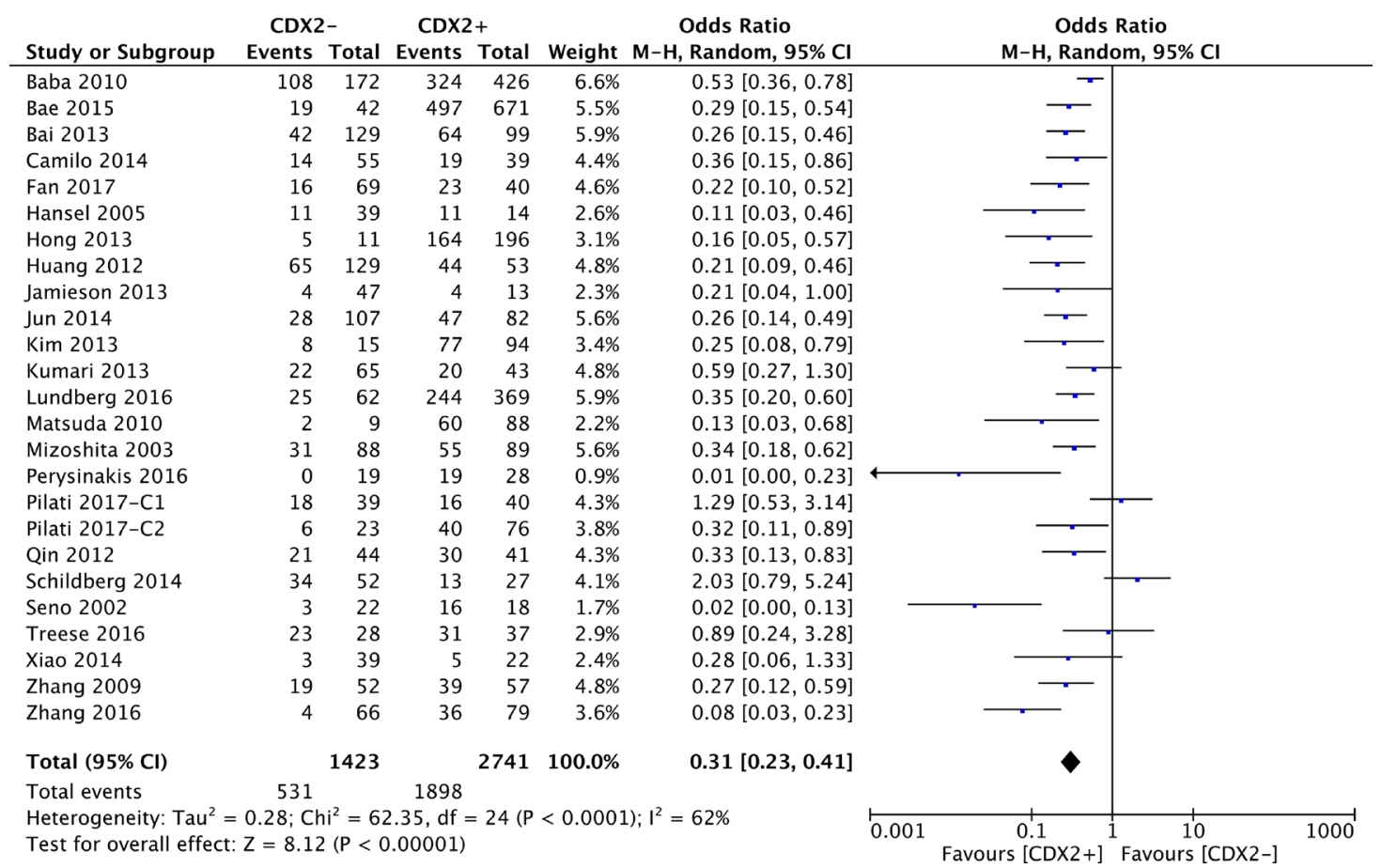

Figure 4: Forest plot of the association between CDX2 expression and 5-year overall survival in solid malignancies. 
CDX2- CDX2+

Odds Ratio

Study or Subgroup Events Total Events Total Weight $\mathrm{M}-\mathrm{H}$, Random, $95 \% \mathrm{Cl}$ 6.6.1 Gastric cancer of 5-year OS

Bai 2013

Camilo 2014

Fan 2017

Mizoshita 2003

Qin 2012

Schildberg 2014

Seno 2002

Zhang 2009

Subtotal $(95 \% \mathrm{CI})$

Total events

$42 \quad 129$

$14 \quad 55$

$64 \quad 99 \quad 6.1 \%$

$0.26[0.15,0.46]$

$0.36[0.15,0.86]$

$0.22[0.10,0.52]$

$0.34[0.18,0.62]$

$0.33[0.13,0.83]$

$2.03[0.79,5.24]$

$0.02[0.00,0.13]$

$0.27[0.12,0.59]$

$0.32[0.18,0.55]$

Heterogeneity: $\mathrm{Tau}^{2}=0.42 ; \mathrm{Chi}^{2}=24.32, \mathrm{df}=7(\mathrm{P}=0.001) ; \mathrm{I}^{2}=71 \%$

Test for overall effect: $Z=4.12(P<0.0001)$

6.6.2 Colorectal cancer of 5-year os

$\begin{array}{lrrrrrr}\text { Baba 2010 } & 108 & 172 & 324 & 426 & 6.9 \% & 0.53[0.36,0.78] \\ \text { Bae 2015 } & 19 & 42 & 497 & 671 & 5.7 \% & 0.29[0.15,0.54] \\ \text { Hong 2013 } & 5 & 11 & 164 & 196 & 3.2 \% & 0.16[0.05,0.57] \\ \text { Kim 2013 } & 8 & 15 & 77 & 94 & 3.5 \% & 0.25[0.08,0.79] \\ \text { Lundberg 2016 } & 25 & 62 & 244 & 369 & 6.1 \% & 0.35[0.20,0.60] \\ \text { Matsuda 2010 } & 2 & 9 & 60 & 88 & 2.2 \% & 0.13[0.03,0.68] \\ \text { Pilati 2017-C1 } & 18 & 39 & 16 & 40 & 4.5 \% & 1.29[0.53,3.14] \\ \text { Pilati 2017-C2 } & 6 & 23 & 40 & 76 & 3.9 \% & 0.32[0.11,0.89] \\ \text { Subtotal (95\% CI) } & & 373 & & \mathbf{1 9 6 0} & \mathbf{3 6 . 0 \%} & \mathbf{0 . 3 7}[\mathbf{0 . 2 5}, 0.56] \\ \text { Total events } & 191 & & 1422 & & & \end{array}$

Total events $191 \quad 1422$

Heterogeneity: $\mathrm{Tau}^{2}=0.15 ; \mathrm{Chi}^{2}=14.47, \mathrm{df}=7(\mathrm{P}=0.04) ; \mathrm{I}^{2}=52 \%$

Test for overall effect: $Z=4.75(P<0.00001)$

6.6.3 Other types of 5-year OS

Hansel 2005

Huang 2012

Jamieson 2013

Jun 2014

Kumari 2013

Perysinakis 2016

Xiao 2014

Zhang 2016

Subtotal $(95 \% \mathrm{Cl})$

Total events $\quad 137 \quad 186$

$\begin{array}{rr}11 & 39 \\ 65 & 129 \\ 4 & 47 \\ 28 & 107 \\ 22 & 65 \\ 0 & 19 \\ 3 & 39 \\ 4 & 66\end{array}$

Test for overall effect: $Z=5.51(P<0.00001)$

Total $(95 \% \mathrm{CI})$

Total events 508

1395

Test for overall effect: $Z=8.24(P<0.00001)$

Test for subgroup differences: $\mathrm{Chi}^{2}=3.02, \mathrm{df}=2(\mathrm{P}=0.22), \mathrm{I}^{2}=33.9 \%$

$0.11[0.03,0.46]$

$0.21[0.09,0.46]$

$0.21[0.04,1.00]$

$0.26[0.14,0.49]$

$0.59[0.27,1.30]$

$0.01[0.00,0.23]$

$0.28[0.06,1.33]$

$0.08[0.03,0.23]$

$0.20[0.11,0.36]$

Odds Ratio

M-H, Random, 95\% CI

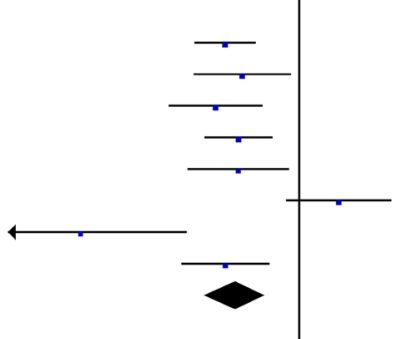

$0.30[0.22,0.40]$

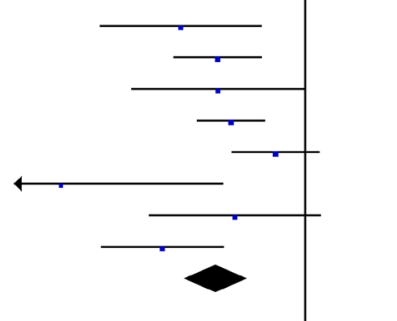

Figure 5: The correlation between CDX2 expression and 5-year overall survival based on different cancer types.

CDX2- CDX2+ Odds Ratio

Study or Subgroup Events Total Events Total Weight M-H, Random, 95\% Cl

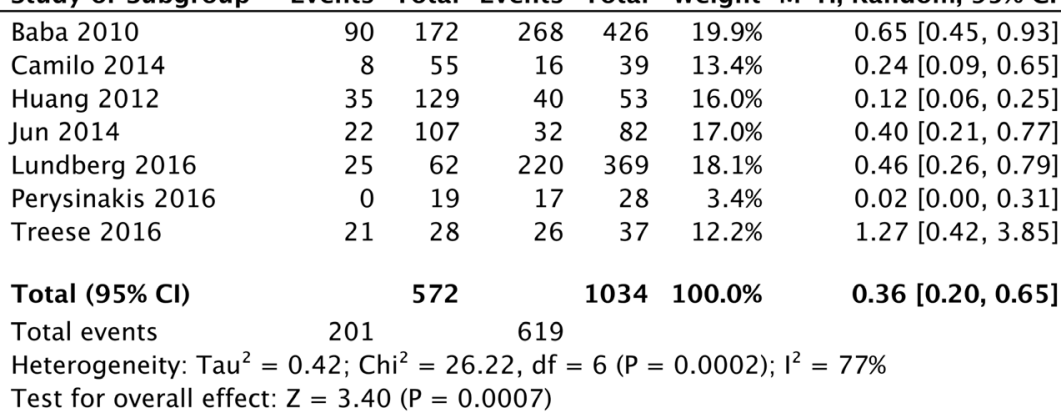

Test for overall effect: $Z=3.40(P=0.0007)$

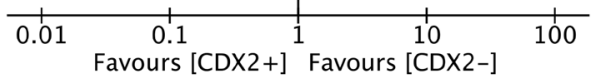


with first-line drugs were extracted. The pooled analysis of retrospective studies suggested that there was no significant difference in the chemotherapeutic effects between patients with low CDX2 expression and higher CDX2 expression in solid malignancies (OR: 0.92, 95\%CI: $[0.45,1.90], P=0.83, I^{2}=82 \%$ ) (Figure 7).

Included studies were divided into two subgroups according to the cancer types, CDX2 expression was not associated with the chemotherapeutic effects in solid malignancies, no matter whether the cancer was colorectal (OR: $0.78,95 \% \mathrm{CI}:[0.33,1.82], P<0.56, I^{2}=83 \%$ ) or ovarian (OR: 1.76, 95\%CI: [0.91, 3.44], $P<0.09$ ) (Figure 9).

As for different TNM stages of solid malignancies, in participants with TNM IV (OR: 0.20, 95\%CI: [0.09,0.43], $P<0.0001)$ stage diseases, higher CDX2 levels were linked to a better chemotherapeutic effects. Nevertheless, regarding patients with I-IV (OR: 1.76, 95\%CI: [0.91,3.44], $P=0.09$ ) and II/III (OR: 1.10, 95\% CI: $[0.71,1.69], P=0.68, I^{2}=25 \%$ ) stage diseases, an equivalent chemotherapeutic effect was obtained between lower CDX2 expression and higher CDX2 expression in solid malignancies (Figure 9).

\section{Sensitivity analysis}

First, we switched the statistical model from the random-effects to the fixed-effects model, and the OS and DFS remained unchanged. A similar result was also observed for studied concerned with cancer relapses and chemotherapeutic effects (Supplementary Table 2).
Second, when included trials were randomly removed, the outcome stability for OS, DFS, cancer relapse and chemotherapeutic effect was graphically confirmed (Supplementary Figures 3, 6-9).

Third, we excluded the low-quality trials conducted by Jamieson 2013 and Wong 2011, and the results of CDX2 expressions that were associated with OS and cancer relapse remained stable (Supplementary Figures 10-12).

\section{Publication bias}

The funnel plots, Egger's test and Begg's test jointly confirmed that there was no publication bias concerning the pooled results except for the results for 5-year OS ( $P$ values were 0.042 and 0.038 ). Thus, we performed a sensitivity analysis using the trim-and-fill method, which suggested that there was a low risk of publication bias $(P=0.000)$ (Supplementary Figure 13-23).

\section{DISCUSSION}

Individual studies have partially revealed the favourable prognostic roles of CDX2 expression in gastric cancers [6]. Nevertheless, from the clinical perspective, the prognostic significance of CDX2 remains unconvincing because the experimental cohorts and participants were too scarce. Whether CDX2 expression is associated with tumour prognosis is worthy of further pursuit. To our knowledge, this meta-analysis is the first comprehensive exploration of the possible prognostic roles of CDX2 in solid malignancies.

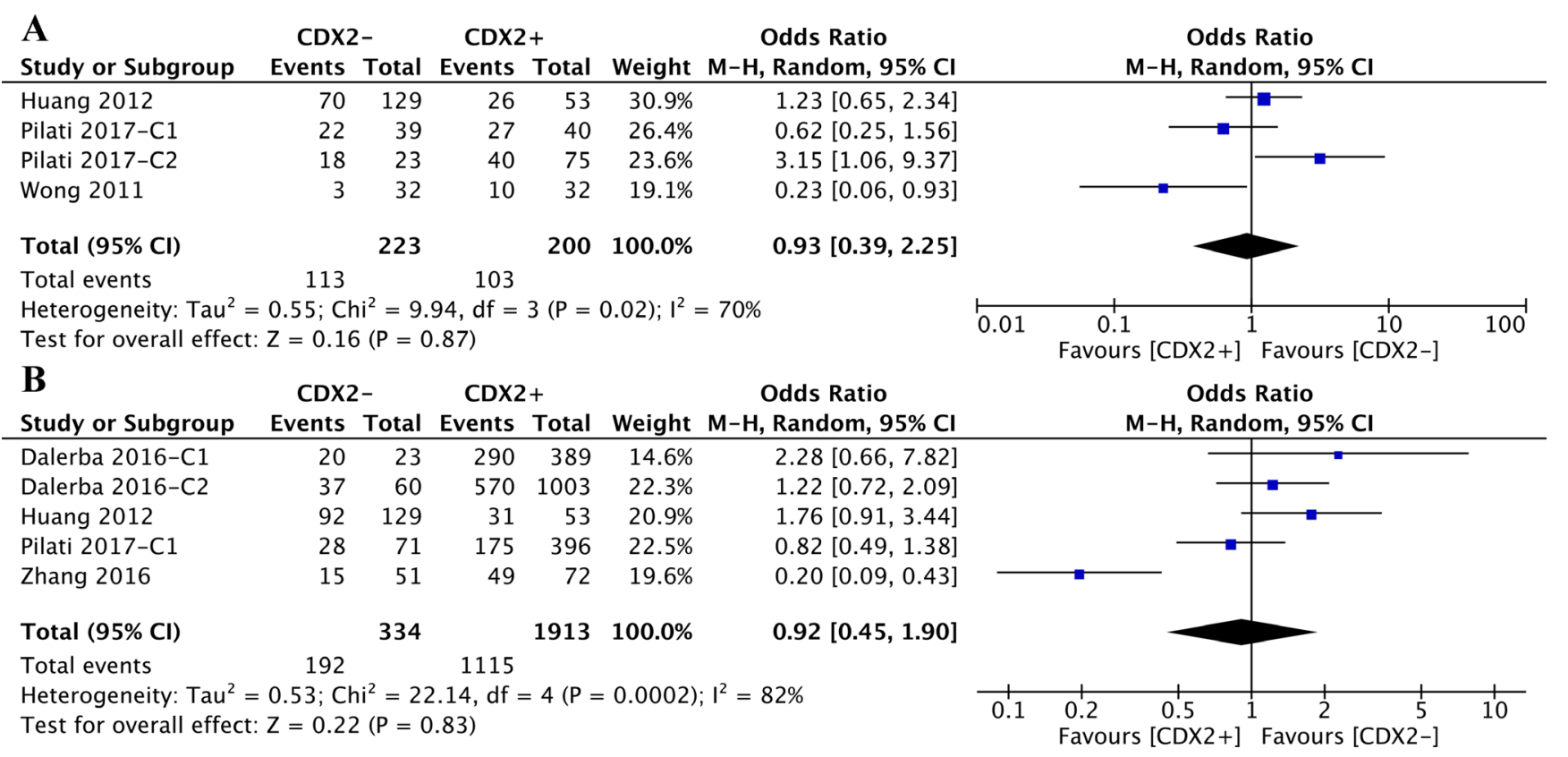

Figure 7: (A) The correlation between CDX2 expression and cancer relapse in solid malignancies. (B) The correlation between CDX2 expression and chemotherapeutic effect in solid malignancies. 
Overall, our quantitative analysis indicates that a beneficial impact of CDX2 redundancy is correlated with better 3-year, 5-year, and 10-year OS and DFS, which does not account for subgroup confounding factors. Additionally, this positive prognostic role was confirmed to be independent of cancer types, mean ages, and sample sizes. Unlike other nuclear transcription factors, CDX2 has been experimentally confirmed to have carcinostatic and carcinogenic roles in various solid malignancies. Multiple researchers have reported that CDX2 could inhibit cell growth which is associated with significant cell cycle arrest at the G0/G1 phase [36]. Several studies have shown that excessive expression of CDX2 could prompt cell apoptosis in malignancies $[37,38]$. However, other studies have suggested that CDX2 can function as an oncogene as well, promoting the proliferation of cells beyond their normal constraints [39, 40]. Our pooled results suggest that despite the presence of its carcinogenic role, the anticancer activity of CDX2 has stronger effects on the clinical prognoses of cancer patients. Additionally, in-depth molecular-level investigations have demonstrated that CDX2 can reduce the expression of downstream target genes, including axis inhibition protein 2 (AXIN2) and lung lineage transcription factor $N k x 2-1$, which subsequently inhibit tumour invasion and metastasis $[41,42]$. This is a potential explanation for the better prognosis that is associated with CDX2 overexpression. Regarding the source regions, European patients displayed

A CDX2- $\quad$ CDX2+ $\quad$ Odds Ratio $\quad$ Odds Ratio

Study or Subgroup Events Total Events Total Weight $\mathrm{M}-\mathrm{H}, \mathrm{Random}, 95 \% \mathrm{Cl} \quad \mathrm{M}-\mathrm{H}, \mathrm{Random}, 95 \% \mathrm{Cl}$

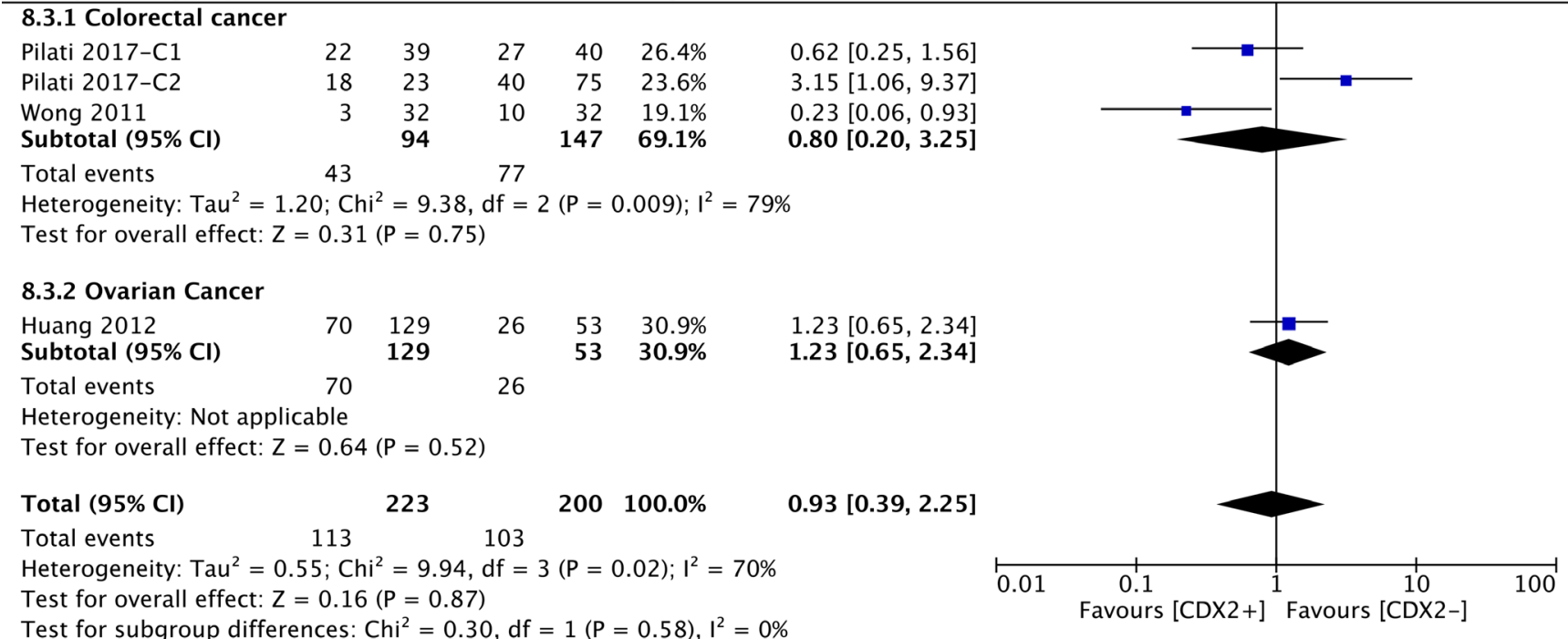

Test for subgroup differences: $\mathrm{Chi}^{2}=0.30, \mathrm{df}=1(\mathrm{P}=0.58), \mathrm{I}^{2}=0 \%$

B CDX2- $\quad$ CDX2+ $\quad$ Odds Ratio Odds Ratio

Study or Subgroup Events Total Events Total Weight M-H, Random, 95\% Cl $\quad$ M- H, Random, 95\% Cl

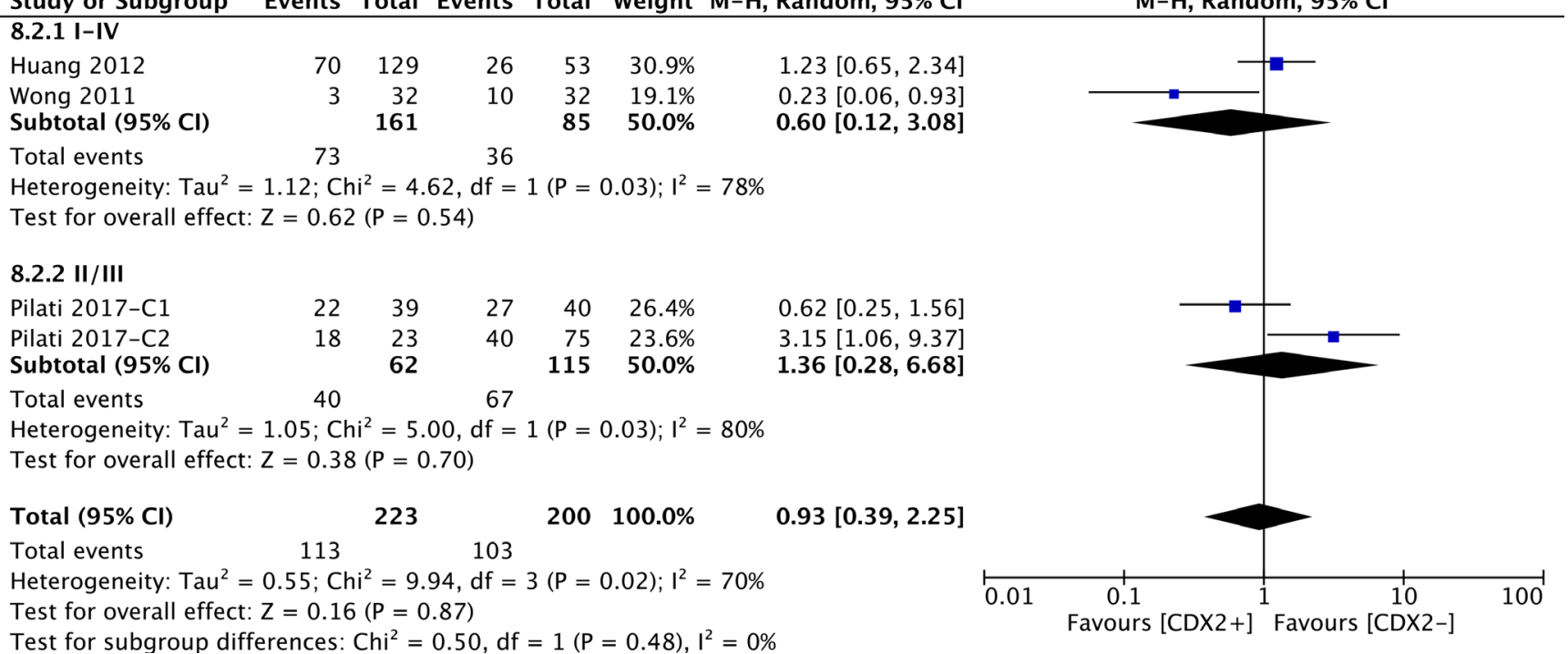

Test for subgroup differences: $\mathrm{Chi}^{2}=0.50, \mathrm{df}=1(\mathrm{P}=0.48), \mathrm{I}^{2}=0 \%$

Figure 8: The correlation between CDX2 expression and cancer relapse. (A) based on different cancer types. (B) based on different TNM stages. 
no obvious connection between CDX2 overexpression and a better prognosis in solid malignancies. The included studies of CDX2 expression and prognosis from the European population are insufficient. Thus, increasing the number of studies may result in consistency with other regions.

Based on our pooled evidence, the CDX2 expression level may not be associated with cancer relapse, and the subgroup analysis for TNM stages and cancer types is consistent with this finding. Additionally, chemotherapeutic resistance is another challenge for therapeutic efficacy and patient prognosis, and our analysis showed that CDX2 overexpression in cancer patients with TNM IV stage diseases had a better response to adjuvant chemotherapy with first-line drugs. This conclusion is reasonable based on the current studies,

\section{A CDX2- CDX2+ Odds Ratio Odds Ratio}

Study or Subgroup Events Total Events Total Weight $\mathrm{M}-\mathrm{H}, \mathrm{Random}, \mathbf{9 5 \%} \mathrm{Cl}$

$\begin{array}{lrrrrrr}\text { 7.3.1 Colorectal cancer } & & & & & & \\ \text { Dalerba 2016-C1 } & 20 & 23 & 290 & 389 & 14.6 \% & 2.28[0.66,7.82] \\ \text { Dalerba 2016-C2 } & 37 & 60 & 570 & 1003 & 22.3 \% & 1.22[0.72,2.09] \\ \text { Pilati 2017-C1 } & 28 & 71 & 175 & 396 & 22.5 \% & 0.82[0.49,1.38] \\ \text { Zhang 2016 } & 15 & 51 & 49 & 72 & 19.6 \% & 0.20[0.09,0.43] \\ \text { Subtotal (95\% Cl) } & & \mathbf{2 0 5} & & \mathbf{1 8 6 0} & \mathbf{7 9 . 1 \%} & \mathbf{0 . 7 8}[\mathbf{0 . 3 3}, \mathbf{1 . 8 2}] \\ \text { Total events } & 100 & & 1084 & & & \end{array}$

Heterogeneity: $\mathrm{Tau}^{2}=0.59 ; \mathrm{Chi}^{2}=17.70, \mathrm{df}=3(\mathrm{P}=0.0005) ; \mathrm{I}^{2}=83 \%$

Test for overall effect: $Z=0.58(P=0.56)$

\subsubsection{Ovarian Cancer}

$\begin{array}{lcccccc}\text { Huang } 2012 & 92 & 129 & 31 & 53 & 20.9 \% & 1.76[0.91,3.44] \\ \text { Subtotal }(\mathbf{9 5 \%} \mathbf{C I}) & & \mathbf{1 2 9} & & \mathbf{5 3} & \mathbf{2 0 . 9 \%} & \mathbf{1 . 7 6}[\mathbf{0 . 9 1 , 3 . 4 4 ]} \\ \text { Total events } & 92 & & 31 & & & \end{array}$

Heterogeneity: Not applicable

Test for overall effect: $Z=1.67(P=0.09)$

Total (95\% Cl)

334

$1913100.0 \%$

$0.92[0.45,1.90]$

Total events 192 1115

Heterogeneity: $\mathrm{Tau}^{2}=0.53 ; \mathrm{Chi}^{2}=22.14, \mathrm{df}=4(\mathrm{P}=0.0002) ; \mathrm{I}^{2}=82 \%$

Test for overall effect: $Z=0.22(P=0.83)$

Test for subgroup differences: $\mathrm{Chi}^{2}=2.21, \mathrm{df}=1(\mathrm{P}=0.14), \mathrm{I}^{2}=54.8 \%$

B CDX2- CDX2+ Odds Ratio

Study or Subgroup Events Total Events Total Weight $\mathrm{M}-\mathrm{H}, \mathrm{Random}, 95 \% \mathrm{Cl}$ 7.2.1 I-IV Huang 2012 Subtotal $(95 \% \mathrm{CI})$ $92 \quad 129$

$\begin{array}{lll}31 & 53 & 20.9 \% \\ & 53 & 20.9 \%\end{array}$

$1.76[0.91,3.44]$

Total events 92

Heterogeneity: Not applicable

Test for overall effect: $Z=1.67(P=0.09)$

7.2.2 II/III

$\begin{array}{lrrrrrr}\text { Dalerba 2016-C1 } & 20 & 23 & 290 & 389 & 14.6 \% & 2.28[0.66,7.82] \\ \text { Dalerba 2016-C2 } & 37 & 60 & 570 & 1003 & 22.3 \% & 1.22[0.72,2.09] \\ \text { Pilati 2017-C1 } & 28 & 71 & 175 & 396 & 22.5 \% & 0.82[0.49,1.38] \\ \text { Subtotal (95\% CI) } & & \mathbf{1 5 4} & & \mathbf{1 7 8 8} & \mathbf{5 9 . 5 \%} & \mathbf{1 . 1 0}[\mathbf{0 . 7 1}, \mathbf{1 . 6 9}] \\ \text { Total events } & 85 & & 1035 & & & \end{array}$

Heterogeneity: $\mathrm{Tau}^{2}=0.04 ; \mathrm{Chi}^{2}=2.68, \mathrm{df}=2(\mathrm{P}=0.26) ; \mathrm{I}^{2}=25 \%$

Test for overall effect: $Z=0.41(P=0.68)$

\subsubsection{IV}

Zhang 2016

Subtotal $(95 \% \mathrm{CI})$

Total events

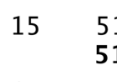

15

Heterogeneity: Not applicable

Test for overall effect: $Z=4.10(P<0.0001)$

Total $(95 \% \mathrm{CI})$

334

Total events 192

$1913100.0 \%$

Heterogeneity: $\mathrm{Tau}^{2}=0.53 ; \mathrm{Chi}^{2}=22.14, \mathrm{df}=4(\mathrm{P}=0.0002) ; \mathrm{I}^{2}=82 \%$

Test for overall effect: $Z=0.22(P=0.83)$

Test for subgroup differences: $\mathrm{Chi}^{2}=19.42$, df $=2(\mathrm{P}<0.0001), \mathrm{I}^{2}=89.7 \%$
M-H, Random, 95\% Cl

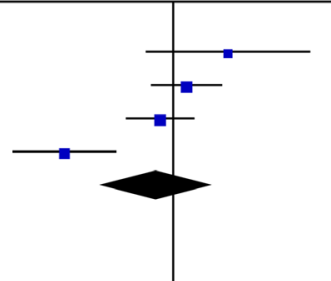

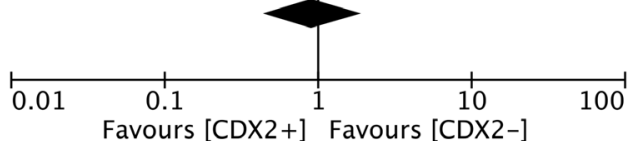

Odds Ratio

M-H, Random, 95\% Cl

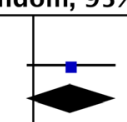

Figure 9: The correlation between CDX2 expression and chemotherapeutic effects. (A) based on different cancer types. (B) based on different TNM stages. 
and CDX2 positivity is associated with microsatellite instability (MSI)-low malignancies, which respond better to chemotherapies than MSI-high malignancies [21, 27]. However, paradoxically, previous studies have confirmed that CDX2 induces the expression of the multidrug resistance protein 1 (MDR1) gene by binding to MDR1 promoter elements [39]. This finding illustrates that CDX2 may affect the response to cancer chemotherapy through multiple mechanisms. Meanwhile, similar results have not been obtained for CDX2 overexpression in cancer patients with TNM I-III stage diseases. In Stage I-II cancers, the adjuvant chemotherapy provides an unsatisfied benefit, which is usually not worth the toxic effects of the drugs. Stage III cancers have regional lymph node metastases, and multiple clinical studies have demonstrated significant increases in survival with the administration of adjuvant chemotherapy [43]. Our analysis lacks individual data for CDX2 expression that is associated with stage III malignancies. An elucidation of how CDX2 expression is associated with MSI status and TNM stage requires further study. Additionally, this result also suggests that chemotherapy may prolong the OS of high-CDX2-level cancer patients with TNM IV stage diseases.

There are several limitations in our meta-analysis. First, although random-effects models and subgroup analyses were used, heterogeneity could not be completely eliminated. This may have led to a specific bias in the results and may suggest that certain clinical elements were not fully analysed, such as tissue types and pathological grades. Moreover, Pilati et al-C1 and Schildberg et al were responsible for most of the internal heterogeneity across the studies because removal of both trials cleared the $I 2$ value completely to $0 \%$ [27]. Schildberg et al attributed the opposite outcomes in the CDX2-positive groups to the unbalanced patient age distribution (i.e., no significant impact on survival with downregulated CDX2 concerning all patients less than 50 years of age) [29]. Nevertheless, our subgroup analysis did not show consistent results regarding the mean ages. Therefore, more pertinent studies are still necessary for further analysis. Second, although the total participant sample size exceeded 5000, the number of included studies was insufficient, especially for the analysis of CDX2 expression with the cancer relapse and the chemotherapeutic effects. Sex and ethnicity differences in biomarkers and response are currently the hot topics, our subgroup analysis failed to obtain these results due to the lack of data in the original study. Therefore, further studies are necessary to address these shortcomings to obtain more convincing conclusions.

Taken together, this meta-analysis demonstrates the beneficial effects of CDX2 overexpression on the life expectancy and prognosis of cancer patients, except for the European populations. In addition, CDX2 overexpression in cancer patients with TNM IV stage diseases performed a better response to adjuvant chemotherapy with first-line drugs. Therefore, we conclude that CDX2 is likely to be an important biomarker for guiding evaluations of clinical practice and prognosis.

\section{MATERIALS AND METHODS}

\section{Literature search}

We performed a systematic literature search using PUBMED and EMBASE up to May 2017 with the following terms as the search strategy: "CDX2 AND (tumor OR cancer OR malignancy OR neoplasm OR adenoma)". Furthermore, we manually screened the references in relevant articles to identify additional articles.

\section{Study selection}

Studies in accordance with the following criteria were included: 1. articles were written in English; 2.the expression of CDX2 was detected by immunohistochemistry; and 3. human studies addressing the correlation between CDX2 expression and clinical prognosis in solid malignancies.

Studies were excluded due to the following reasons: 1. inadequate survival data for further statistical analysis; 2. a follow-up duration that was shorter than 3 years; 3 . duplicated or overlapping studies; 4. inappropriate article types such as reviews or case-reports; and 5. studies based on a sample size that comprised less than 10 participants.

\section{Data extraction}

Using predefined standardized extraction forms, two investigators independently extracted data from each qualified study. The general information, namely, 3-year OS, 5-year OS, 10-year OS, DFS, cancer relapse and chemotherapeutic effect was documented. The original survival data were obtained from the text, tables or Kaplan-Meier curves for both comparative groups.

\section{Methodological assessment}

The NOS was used to quantitatively evaluate the included study quality. Studies graded with more than six scores using the methodology with a maximum score of nine were identified as high-quality trials.

\section{Statistical analysis}

We summarized the pooled outcomes using forest plots (Review Manager version 5.3) and calculated the $I^{2}$ as a measure of heterogeneity. $I^{2}$ values were prespecified to indicate low $(<25 \%)$, moderate $(25 \%-50 \%)$, and high $(>50 \%$ ) heterogeneity. $P$ values less than 0.05 were considered significant. Moreover, a sensitivity analysis was applied to examine the stability of the results. We 
visually assessed the funnel plots and used the Egger's test and Begg's test to assess the publication bias (STATA/MP version 14.0). We performed the trim-and-fill procedure to further evaluate the possible publication bias on our meta-analysis. Two investigators separately reviewed the eligible studies and extracted the data, and a joint decision was made in cases of disagreement.

\section{ACKNOWLEDGMENTS}

We sincerely appreciate our team members for providing statistical instructions.

\section{CONFLICTS OF INTEREST}

The authors declare no conflicts of interest.

\section{FUNDING}

This work was supported by grants from the National Natural Science Foundation of China (No. 81572411).

\section{REFERENCES}

1. Hutchinson L. Gastrointestinal cancer: CDX2: prognostic marker for high-risk colon cancer. Nat Rev Clin Oncol. 2016; 13:134-5.

2. Baba Y, Nosho K, Shima K, Freed E, Irahara N, Philips J, Meyerhardt JA, Hornick JL, Shivdasani RA, Fuchs CS, Ogino S. Relationship of CDX2 Loss with Molecular Features and Prognosis in Colorectal Cancer. Clin Cancer Res. 2009; 15:4665-73.

3. Nolte S, Zlobec I, Lugli A, Hohenberger W, Croner R, Merkel S, Hartmann A, Geppert CI, Rau TT. Construction and analysis of tissue microarrays in the era of digital pathology: a pilot study targeting CDX1 and CDX2 in a colon cancer cohort of 612 patients. J Pathol Clin Res. 2017; 3:58-70.

4. Xie Y, Li L, Wang X, Qin Y, Qian Q, Yuan X, Xiao Q. Overexpression of $\mathrm{Cdx} 2$ inhibits progression of gastric cancer in vitro. Int J Oncol. 2010; 36:509-16.

5. Grimminger P, Ling FC, Neiss S, Vallböhmer D, Lurje G, Schneider PM, Hölscher AH, Metzger R, Brabender J. The role of the homeobox genes BFT and CDX2 in the pathogenesis of non-small cell lung cancer. Anticancer Res. 2009; 29:1281-6.

6. Wang XT, Wei WY, Kong FB, Lian C, Luo W, Xiao Q, Xie YB. Prognostic significance of $\mathrm{Cdx} 2$ immunohistochemical expression in gastric cancer: a meta-analysis of published literatures. J Exp Clin Cancer Res. 2012; 31:98.

7. Olsen J, Espersen ML, Jess P, Kirkeby LT, Troelsen JT. The clinical perspectives of CDX2 expression in colorectal cancer: a qualitative systematic review. Surg Oncol. 2014; 23:167-76.
8. Dalerba P, Sahoo D, Clarke MF. CDX2 as a Prognostic Biomarker in Colon Cancer. N Engl J Med. 2016; 374:2184.

9. Li QL, Yang ZL, Liu JQ, Miao XY. Expression of CDX2 and Hepatocyte Antigen in Benign and Malignant Lesions of Gallbladder and Its Correlation with Histopathologic Type and Clinical Outcome. Pathol Oncol Res. 2011; 17:561-8.

10. Baba Y, Nosho K, Shima K, Freed E, Irahara N, Philips J, Meyerhardt JA, Hornick JL, Shivdasani RA, Fuchs CS, Ogino S. Relationship of CDX2 loss with molecular features and prognosis in colorectal cancer. Clin Cancer Res. 2009; 15:4665-73.

11. Bae JM, Lee TH, Cho NY, Kim TY, Kang GH. Loss of CDX2 expression is associated with poor prognosis in colorectal cancer patients. World J Gastroenterol. 2015; 21:1457-67.

12. Bai ZG, Ye YJ, Shen DH, Lu YY, Zhang ZT, Wang S. PTEN expression and suppression of proliferation are associated with $\mathrm{Cdx} 2$ overexpression in gastric cancer cells. Int $\mathrm{J}$ Oncol. 2013; 42:1682-91.

13. Camilo V, Barros R, Celestino R, Castro P, Vieira J, Teixeira MR, Carneiro F, Pinto-de-Sousa J, David L, Almeida R. Immunohistochemical molecular phenotypes of gastric cancer based on SOX2 and CDX2 predict patient outcome. BMC Cancer. 2014; 14:753.

14. Dalerba P, Sahoo D, Paik S, Guo X, Yothers G, Song N, Wilcox-Fogel N, Forgó E, Rajendran PS, Miranda SP, Hisamori S, Hutchison J, Kalisky T, Qian D, Wolmark N, Fisher GA, van de Rijn M, Clarke MF. CDX2 as a Prognostic Biomarker in Stage II and Stage III Colon Cancer. N Engl J Med. 2016; 374:211-22.

15. Fan Z, Li J, Dong B, Huang X. Expression of Cdx2 and hepatocyte antigen in gastric carcinoma: correlation with histologic type and implications for prognosis. Clin Cancer Res. 2005; 11:6162-70.

16. Hansel DE, Maitra A, Lin JW, Goggins M, Argani P, Yeo CJ, Piantadosi S, Leach SD, Biankin AV. Expression of the caudal-type homeodomain transcription factors CDX $1 / 2$ and outcome in carcinomas of the ampulla of Vater. $\mathrm{J}$ Clin Oncol. 2005; 23:1811-8.

17. Hong KD, Lee D, Lee Y, Lee SI, Moon HY. Reduced CDX2 expression predicts poor overall survival in patients with colorectal cancer. Am Surg. 2013; 79:353-60.

18. Huang LP, Yu YH, Sheng C, Wang SH. Up-regulation of cadherin 17 and down-regulation of homeodomain protein CDX2 correlate with tumor progression and unfavorable prognosis in epithelial ovarian cancer. Int J Gynecol Cancer. 2012; 22:1170-6.

19. Jamieson NB, Mohamed MA, Oien K, Duthie F, Dickson EJ, Carter R, McKay C. Molecular Pathological Phenotypes and Outcome in Pancreatic Ductal Adenocarcinoma. Gastroenterology. 2013; 144:S1059.

20. Jun SY, Eom DW, Park H, Bae YK, Jang KT, Yu E, Hong SM. Prognostic significance of CDX2 and mucin expression in small intestinal adenocarcinoma. Mod Pathol. 2014; 27:1364-74. 
21. Kim JH, Rhee YY, Bae JM, Cho NY, Kang GH. Loss of CDX2/CK20 expression is associated with poorly differentiated carcinoma, the $\mathrm{CpG}$ island methylator phenotype, and adverse prognosis in microsatellite-unstable colorectal cancer. Am J Surg Pathol. 2013; 37:1532-41.

22. Kumari N, Prabha K, Singh RK, Baitha DK, Krishnani N. Intestinal and pancreatobiliary differentiation in periampullary carcinoma: the role of immunohistochemistry. Hum Pathol. 2013; 44:2213-9.

23. Lundberg IV, Edin S, Eklöf V, Öberg A, Palmqvist R, Wikberg ML. SOX2 expression is associated with a cancer stem cell state and down-regulation of CDX2 in colorectal cancer. BMC Cancer. 2016; 16:471.

24. Matsuda M, Sentani K, Noguchi T, Hinoi T, Okajima M, Matsusaki K, Sakamoto N, Anami K, Naito Y, Oue N, Yasui W. Immunohistochemical analysis of colorectal cancer with gastric phenotype: claudin-18 is associated with poor prognosis. Pathol Int. 2010; 60:673-80.

25. Mizoshita $\mathrm{T}$, Tsukamoto $\mathrm{T}$, Nakanishi $\mathrm{H}$, Inada $\mathrm{K}$, Ogasawara N, Joh T, Itoh M, Yamamura Y, Tatematsu M. Expression of $\mathrm{Cdx} 2$ and the phenotype of advanced gastric cancers: relationship with prognosis. J Cancer Res Clin Oncol. 2003; 129:727-34.

26. Perysinakis I, Minaidou E, Mantas D, Sotiropoulos GC, Leontara V, Tsipras H, Zografos GN, Margaris I, Kouraklis G. Differentiation and prognostic markers in ampullary cancer: Role of p53, MDM2, CDX2, mucins and cytokeratins. Pathol Res Pract. 2016; 212:1039-1047.

27. Pilati C, Taieb J, Balogoun R, Marisa L, de Reyniès A, Laurent-Puig P. CDX2 prognostic value in stage II/III resected colon cancer is related to CMS classification. Ann Oncol. 2017; 28:1032-1035.

28. Qin R, Wang NN, Chu J, Wang X. Expression and significance of homeodomain protein $\mathrm{Cdx} 2$ in gastric carcinoma and precancerous lesions. World J Gastroenterol. 2012; 18:3296-302.

29. Schildberg CW, Abba M, Merkel S, Agaimy A, Dimmler A, Schlabrakowski A, Croner R, Leupold JH, Hohenberger W, Allgayer H. Gastric cancer patients less than 50 years of age exhibit significant downregulation of E-cadherin and CDX2 compared to older reference populations. Adv Med Sci. 2014; 59:142-6.

30. Seno H, Oshima M, Taniguchi MA, Usami K, Ishikawa TO, Chiba T, Taketo MM. CDX2 expression in the stomach with intestinal metaplasia and intestinal-type cancer: Prognostic implications. Int J Oncol. 2002; 21:769-74.

31. Treese C, Sanchez P, Grabowski P, Berg E, Bläker H, Kruschewski M, Haase O, Hummel M, Daum S. Poorly Differentiated Medullary Phenotype Predicts Poor Survival in Early Lymph Node-Negative Gastro-Esophageal Adenocarcinomas. PLoS One. 2016; 11:e0168237.

32. Wong SC, Ng SS, Cheung MT, Luk LY, Chan CM, Cheung AH, Lee VH, Lai PB, Ma BB, Hui EP, Lam MY,
Au TC, Chan AT. Clinical significance of CDX2-positive circulating tumour cells in colorectal cancer patients. Br J Cancer. 2011; 104:1000-6.

33. Xiao W, Hong H, Awadallah A, Zhou L, Xin W. Utilization of CDX2 expression in diagnosing pancreatic ductal adenocarcinoma and predicting prognosis. PLoS One. 2014; 9:e86853.

34. Zhang X, Tsukamoto T, Mizoshita T, Ban H, Suzuki H, Toyoda T, Tatematsu M. Expression of osteopontin and CDX2: indications of phenotypes and prognosis in advanced gastric cancer. Oncol Rep. 2009; 21:609-13.

35. Zhang BY, Jones JC, Briggler AM, Hubbard JM, Kipp BR, Sargent DJ, Dixon JG, Grothey A. Lack of CaudalType Homeobox Transcription Factor 2 Expression as a Prognostic Biomarker in Metastatic Colorectal Cancer. Clin Colorectal Cancer. 2017; 16:124-128.

36. Aoki K, Kakizaki F, Sakashita H, Manabe T, Aoki M, Taketo MM. Suppression of colonic polyposis by homeoprotein CDX2 through its nontranscriptional function that stabilizes p27Kip1. Cancer Res. 2011; 71:593-602.

37. Naito Y, Oue N, Hinoi T, Sakamoto N, Sentani K, Ohdan H, Yanagihara K, Sasaki H, Yasui W. Reg IV is a direct target of intestinal transcriptional factor CDX2 in gastric cancer. PLoS One. 2012; 7:e47545.

38. Zhang JF, Zhang JG, Kuai XL, Zhang H, Jiang W, Ding WF, Li ZL, Zhu HJ, Mao ZB. Reactivation of the homeotic tumor suppressor gene CDX2 by 5-aza-2'-deoxycytidineinduced demethylation inhibits cell proliferation and induces caspase-independent apoptosis in gastric cancer cells. Exp Ther Med. 2013; 5:735-741.

39. Takakura Y, Hinoi T, Oue N, Sasada T, Kawaguchi Y, Okajima M, Akyol A, Fearon ER, Yasui W, Ohdan H. CDX2 regulates multidrug resistance 1 gene expression in malignant intestinal epithelium. Cancer Res. 2010; 70:6767-78.

40. Cowan ML, Li QK, Illei PB. CDX-2 Expression in Primary Lung Adenocarcinoma. Appl Immunohistochem Mol Morphol. 2016; 24:16-9.

41. Olsen AK, Coskun M, Bzorek M, Kristensen MH, Danielsen ET, Jørgensen S, Olsen J, Engel U, Holck S, Troelsen JT. Regulation of APC and AXIN2 expression by intestinal tumor suppressor CDX2 in colon cancer cells. Carcinogenesis. 2013; 34:1361-9.

42. Li CM, Gocheva V, Oudin MJ, Bhutkar A, Wang SY, Date SR, Ng SR, Whittaker CA, Bronson RT, Snyder EL, Gertler FB, Jacks T. Foxa2 and Cdx2 cooperate with Nkx21 to inhibit lung adenocarcinoma metastasis. Genes Dev. 2015; 29:1850-62.

43. Boland CR, Goel A. Prognostic Subgroups among Patients with Stage II Colon Cancer. N Engl J Med. 2016; 374:277-8. 